\title{
二次元矩形断面構造物に作用する振動依存風力特性に関する基礎的研究 MOTION-INDUCED WIND FORCES ON TWO DIMENSIONAL LONG AFTER RECTANGULAR MODELS
}

\author{
大 熊 武司*，丸川 比佐夫**，片 桐 純 治***，鶴 見 俊 雄**** \\ Takeshi OHKUMA, Hisao MARUKAWA, Junji KATAGIRI \\ and Toshio TSURUMI
}

\begin{abstract}
Motion-induced wind forces on two-dimensional rectangular section models with aspect ratio 1, 2 and 3 are investigated by a wind tunnel test using uniform turbulent flow. In this study, the motion-induced wind pressures and wind forces during across-wind vibration and torsional vibration are measured by forced-oscillation method. Furthermore, the wind responses of two dimensional rectangular structures are estimated by spectrum modal analysis using the motion-induced wind forces measured in this study, and the analytical results are compared with the free vibration experimental results.
\end{abstract}

Keywords : $\begin{aligned} & \text { Forced-oscillation method, Across-wind vibration, Torsional vibration, } \\ & \text { Motion-induced wind force, Two dimensional model } \\ & \text { 強制振動法, 風直角方向振動, 㧖れ振動, 振動依存風力, 二次元模型 }\end{aligned}$

\section{1.はじめに}

超高層建築物あるいは大スパン構造物といった超大，軽量・低 減衰構造物の出現に伴って, 構造物の不安定振動の発生の有無の 検討が設計段階で重要になる．高無次元風速での風直角方向の不 安定振動，いわゆるギャロッピングに関しては，準定常理論によ り検討できる事が多くの研究により明らかになっている1).それ以 外の自励的渦励振およびフラッターに関しては淮定常理論による 検討はほとんど不可能である．自励的渦励振およびフラッターに 関寸る研究は,超大吊り橋を対象とした橋梁関係に多く見られ，そ の発生要因は解明されつつある2).これらの振動あるいは, 振動時 の風力特性は形状にもよるが，接近流に含まれる乱れによって影 響を受ける事が指摘されている3) 8).

本研究は, 高層建築物を対象とする際に必要となる乱流中にお ける振動時の風力特に振動依存風力の特性の把握および不安定振 動の発生に関する知見を得る事を目的とし, その第一段階として, 振動時の二次元矩形断面模型に作用する振動依存風力性状を明ら かにした．本研究では，模型の振動は強制加振によって与え，風 力測定は力の場が詳細に吟味できる事より風圧測定によって行っ た. また，測定した振動依存風力を用いて二次元構造物の応答予
測を行い，自由振動実験結果と比較した.

\section{2. 実験方法}

使用風洞は神奈川大学所有の吹出し型境界層風洞である.使用 模型は，図-1に示すように辺長比 $D / B=1,2$ および $3(D$ : 奥行き, $B$ : 見附幅) の矩形断面二次元模型である. 風圧測定孔は，模型のスパ ン中央に設け，両端部には直径 $34 \mathrm{~cm}$ の端板を取り付けてある. 模 型への振動は，風洞床下に設けた強制振動装置 (図-2)によって与 え, 振動形態は模型の取りつけ位置を変える事で風直角方向振動, 据れ振動および風直角・㧖り連成振動を与える事が出来る．本論 文では, 図-3に示寸風直角方向および据れ振動時の結果について 報告する.なお，ここでいう㧖れ振動とは，回転中心を模型断面 中心とした振動である. 風直角方向振動時の無次元加振振幅 $A^{*}$ $(=A / B, A$ : 風直角方向加振片振幅) は $0.008 \sim 0.067$, 㨭孔振動時の 加振振幅 $\theta(\theta$ : 回転角片振幅 rad.) は0.005 0.02(本論文では主に 無次元加振振幅 $\theta^{*}=\theta \mathrm{D} / 2 \mathrm{~B}$ で表している) とした. 実験風速は, $4 \sim$ $8 \mathrm{~m} / \mathrm{s}$ であり，加振振動数 $f_{0}$ および模型見附幅による無次元風速 $U^{*}\left(=U / f_{0} B\right)$ は $3 \sim 26$ である. 実験気流は, 乱流格子により作成し た乱れ強さ $8 \%$, 乱れのスケール $4 \mathrm{~cm}$ の一様乱流である.

\footnotetext{
本論文は文献15)に加筆・修正したものである。

* 神奈川大学建築学科 教授・工博

** 侏泉創建エンジニアリング構造システム研究公 室長

*** 侏風工学研究所 主任研究員

***** 佐藤工業(侏)中央技術研究所工修
}

Prof., Kanagawa University, Dep. of Arch., Dr. Eng.

General Manager, R \& D, Izumi Sohken Engineering Co., Ltd.

Chief Research Eng., Wind Engineering Institute Co., Ltd.

Engineering Research Center, Sato Kogyo Co., Ltd., M. Eng. 


\section{3. 実験結果}

\section{1 平均風圧係数}

図-4に風直角方向および摸れ振動時における側面の平均風圧倸 数分布を示寸.

辺長比 1 の場合, 風直角方向振動時には振動の影響が顕著では ないが，据れ振動時には振動の影響を受け，平均風圧係数は全体

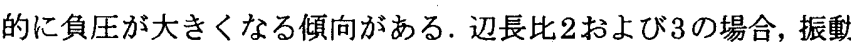
形態に関係なく振動の影響を受け，中央より風上側の領域で負圧 が大きくなっている.

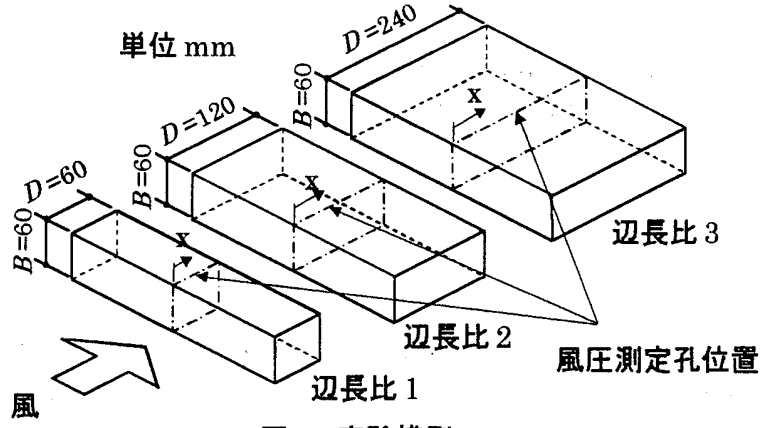

图-1 実験模型

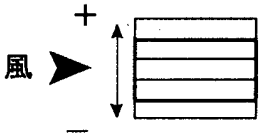

風直角方向振動

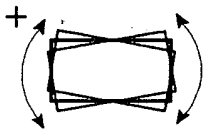

据れ振動

图 -3 振動形態

A* $0: 0.067$
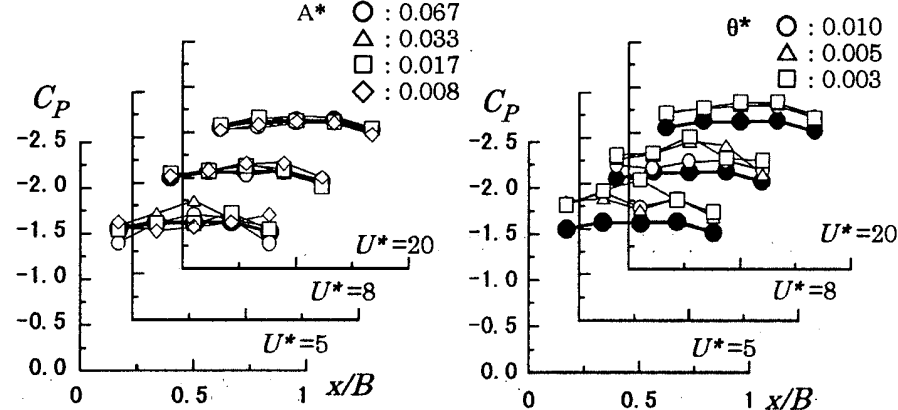

辺長比
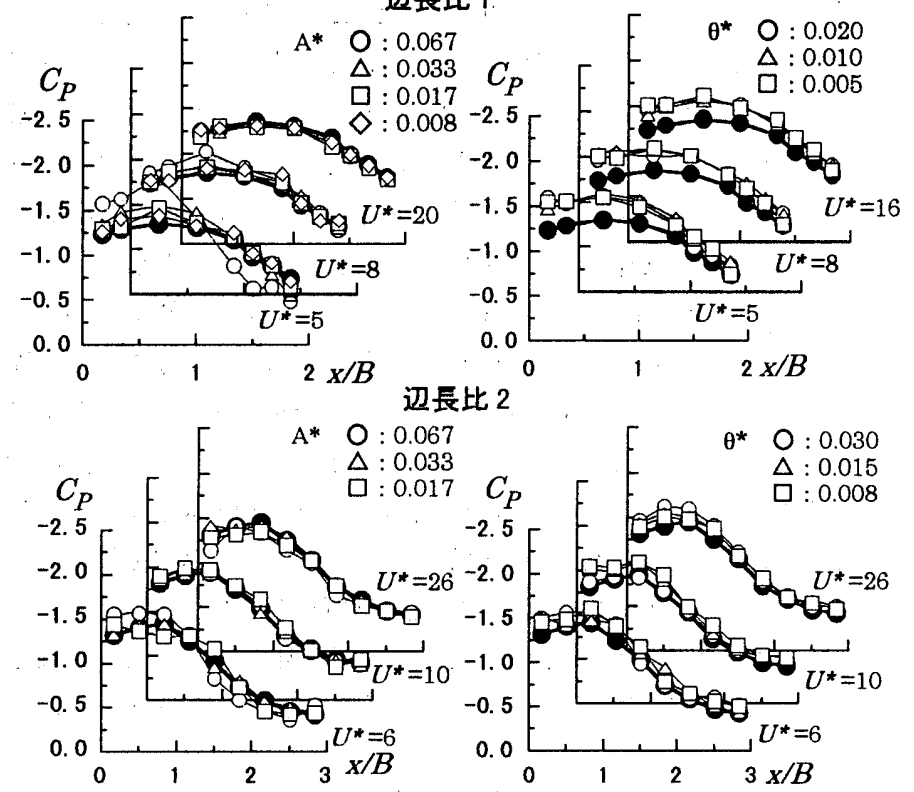

辺長比 3
(a) 風直角方向振動時
(b) 㨝れ振動時

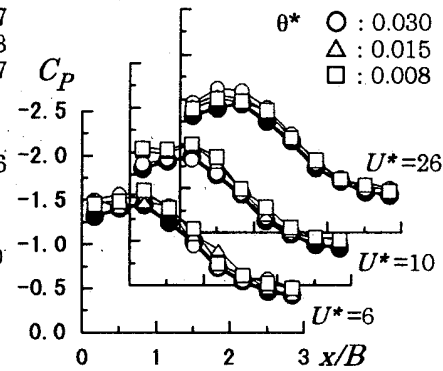

図-4 側壁面の平均風圧係数分布（○：非振動時を示す）

\section{2 変動風圧係数}

図-5に風直角方向および㨭れ振動時の側面の变動風圧係数分布 を示す。

辺長比 1 の場合, 風直角方向振動時には, 概して非振動時に比 ベ変動風圧係数は全体的に若干小さくなる傾向がある. 辺長比 2 および 3 の風直角方向振動時の, 低風速時 (辺長比 $2 の U^{*} \leq 5$, 辺 長比 3 の $\left.U^{*} \leq 6\right)$ では, 振動の影響を顕著に受け, 風上側と風下側 にピークが見られる. 辺長比 3 の場合, 高風速時の変動風圧係数 は, 非振動時に比べ小さくなる。

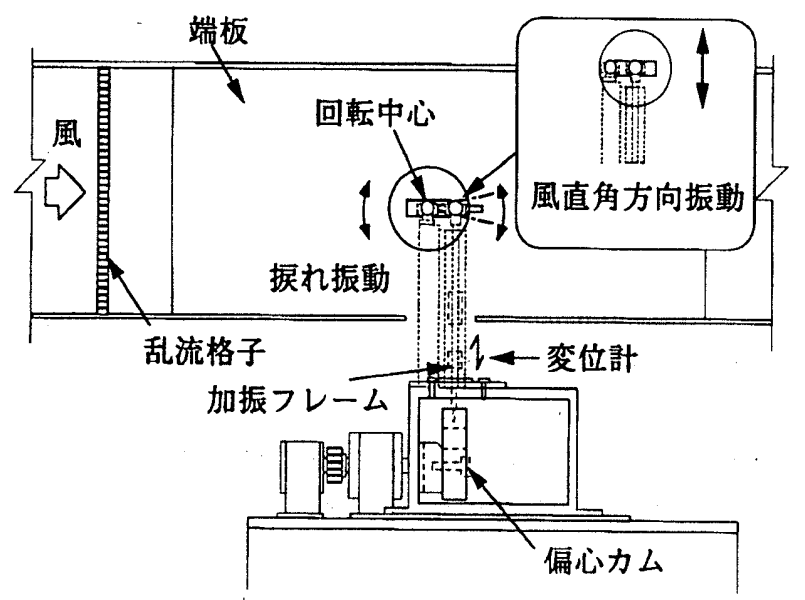

図-2 強制振動装置
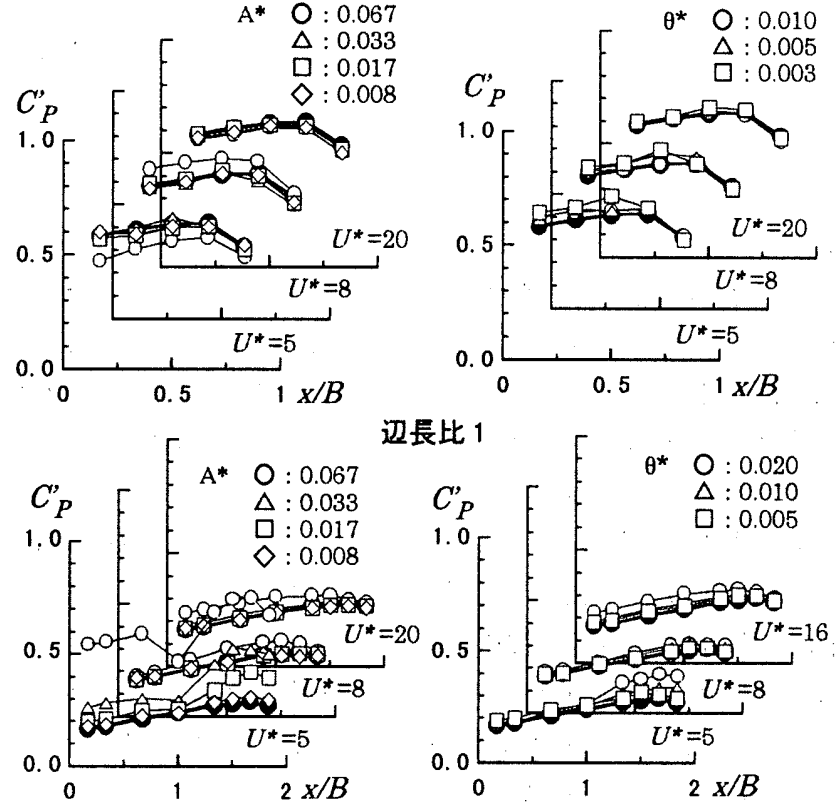

辺長比 2



辺長比 3
（a）風直角方向振動時
(b) 㨭れ振動時

図 -5 側壁面の変動風圧係数分布 (○：非振動時を示す) 


\section{3 変動風圧のパワースペクトル密度および流れ方向の空間的位相差}

図-6および図-7に風上端部より約 $3 \mathrm{D} / 4$ 風下の測定点の非振動時と風直角方向振動時の 変動風圧のパワースペクトル密度および流れ方向の 2 点間の空間的位相差を示す.

辺長比 1 の場合, 風直角方向振動時のパワースペクトル密度形状は, 非振動時と類似し, $U^{*} \doteqdot 8$ にピークを有する. 位相差も，振動の影響は顕著でなく非振動時によく類似してい る. 辺長比 2 および 3 の場合, 風直角方向振動時のパワースペクトル密度は, 加振振動数 に基づく無次元風速 $U^{*}$ 䓃非振動時のパワースペクトル密度のピーク振動数に対応する無 次元風速 $U^{*}{ }_{S P}$ (辺長比 2 の場合 $U_{S P}^{*} \doteqdot 5$, 辺長比 3 の場合 $U^{*}{ }_{S P} \doteqdot 6$ ) 以下において, 加振振 動数付近に顕著なピークが見られる．位相差は， $U^{*} \leq U^{*}{ }_{S P}$ においては，振動の影響を受 け, $f \xi / U$ ( $\xi: 2$ 点間距離) が約 0.1 以下の低無次元振動数で位相の遅れが大きくなる傾向が ある. $U^{*} \geq U^{*}{ }_{S P}$ では，位相差は非振動時の形状に類似している。

以上の傾向は，㨭れ振動時にも見られる.

\section{4 振動依存風圧係数}

振動依存風圧は, 変動風圧に加振振動数の約 3 倍の周波数のローパスフィルターを介した風圧 データから得られたものである，変位についても 同様にローパスフィルターを介した. サンプリン グ周波数は加振振動数の約 40 倍とし, サンプリン グ個数は8192個とした. 加振速度データは, 加振 変位データのフーリエ倸数に角振動数 $\omega$ を掛けて 逆フーリエ変換して求めた.

振動依存風圧係数の変位比例成分 $C_{P R}$, 速度比 例成分 $C_{P I}$ および変位と振動依存風力の位相差 $\beta_{P}$ は下式により求めた。

$C_{P R}=\frac{2}{T q} \int_{0}^{T} P_{i}(t) \frac{\eta(t)}{\eta_{0}} d t$

$C_{P I}=\frac{2}{T q} \int_{0}^{T} P_{i}(t) \frac{\dot{\eta}(t)}{\dot{\eta}_{0}} d t$

$\beta_{P}=\tan ^{-1}\left(\frac{C_{P I}}{C_{P R}}\right)$

ここに, $T:$ 平均時間, $q:$ 速度圧, $P_{i}(t): i$ 点の 変動風圧, $\eta(t):$ 変位あるいは回転角, $\eta_{0}: \eta$ の片 振幅, $\dot{\eta}(t)$ : 速度あるいは角速度, $\dot{\eta}_{0}: \dot{\eta}$ の片振幅 である.なお, 変位, 回転角はそれぞれ上向き, 時 計周りを正とした.得られた振動依存風圧係数は, $A^{*}(=A / B)$ および $\theta^{*}(=\theta D / 2 B)$ で基準化した.

図-8に不安定振動に関係する振動依存風圧係数の速度比例成分 および変位との位相差を示す。

風直角方向振動時 辺長比 1 の場合, 速度比例成分の值は, $U^{*}<U^{*}{ }_{S P}\left(U^{*}{ }_{S P} \doteqdot 8\right)$ では全測定点において負であり，風下側にな るほど負の值が大きくなる．また， $U^{*} \geq U_{S P}^{*}$ では，速度比例成分 は全測定点で正となるが，風下になるほどその值は小さくなる。 $U^{*}$ 六 $U_{S P}^{*}$ では, 加振振幅による振動依存風圧倸数の変化が見られ るが, 他の風速では振動依存風力は加振振幅にほぼ比例している.

変位との位相差は， $U^{*}<U^{*}{ }_{S P}$ では風上において 0 付近であるが, 風下に行くにしたがい低减する. $U^{*} \doteqdot U^{*}{ }_{S P}$ で位相差は全測定点で 負から正に変化する. $U^{*}>U^{*}{ }_{S P}$ の場合, 風下端部付近のみで位相 差は負の值を示す.

辺長比 2 の場合, $U^{*} \leq U^{*}{ }_{S P}\left(U^{*}{ }_{S P} \fallingdotseq 5\right)$ において, 速度比例成分 は中央付近から風上の領域で負の值, 風下の領域で正の值を示す.

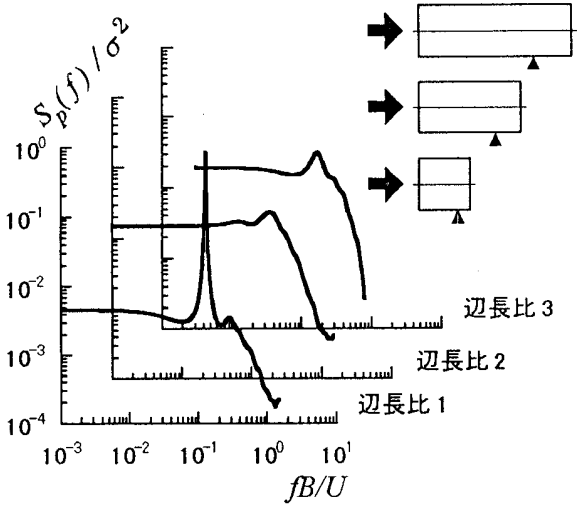

(a) 非振動時

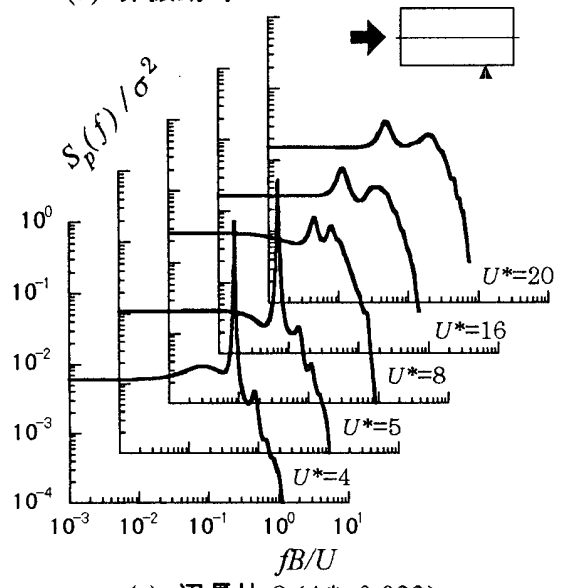

(c) 辺長比 $2\left(\mathrm{~A}^{*}=0.033\right)$

図-6 変動風圧のパワースペクトル密度 (風直角方向振動時)

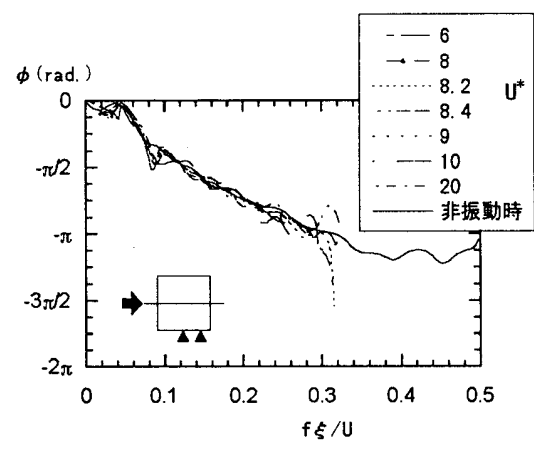

(a) 辺長比 1

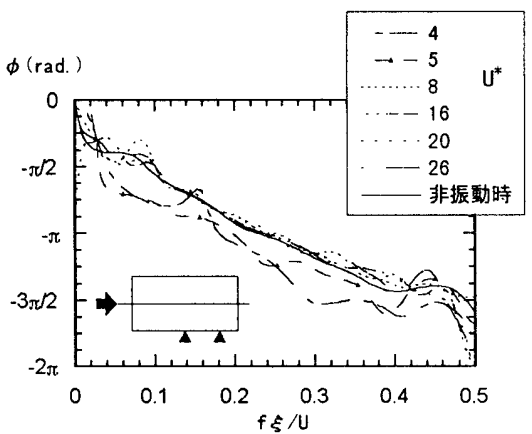

(b) 辺長比 2
図 -7 空間位相差 (風直角方向振動時 $A^{*}=0.033$ )

辺長比 3 の場合 $U^{*} \leq U^{*}{ }_{S P}\left(U^{*}{ }_{S P} \doteqdot 6\right)$ では, 速度比例成分は中央部 では正の值, 端部で負の值を示寸. 辺長比 2,3 とも $U^{*} \geq U^{*}{ }_{S P}$ では, 速度比例成分は無次元風速の増加に伴い正となる領域は風下側一 と移動し狭く，速度比例成分の值も小さくなる．加振振幅による 差は， $U_{S P}^{*}$ 以下の風速で見られるが， $U^{*} \geq U^{*}{ }_{S P}$ では加振振幅にほ ぼ比例する，低風速時における振動依存風圧の速度比例成分の傾 向は山田他 ${ }^{9)}$ の一様乱流中での結果と一致する。

辺長比 2,3 の場合の位相差は, $U^{*} \leq U^{*}{ }_{S P}$ で風上端部付近では風 下側になるにつれて緩やかに低減する， $U^{*} \geq U^{*}{ }_{S P}$ では，風上端部 付近では位相は一定であるが, 中央より風下側では位相差が直線 的に変化する.

据れ振動時 辺長比 1 の場合, 速度比例成分および位相差の定性 的な傾向は，風直角方向振動時に類似している。

辺長比 2,3 場合, 速度比例成分の定性的傾向は風直角方向振 動時によく類似しているが， $U^{*} \leq U^{*}{ }_{S P}$ で風上端部におうる值は小 
さく, $U^{*} \geq 16$ の場合, 速度比例成分は中央より風上で正, 風下で 負の值を示す. 辺長比 2,3 の位相差は, 定性的傾向は風直角方向 振動時に類似している.

\section{5 振動依存風力}

振動依存揚力係数 $C_{L R(I)}$, 掘りモーメント係数 $C_{M R(I)}$ および変位
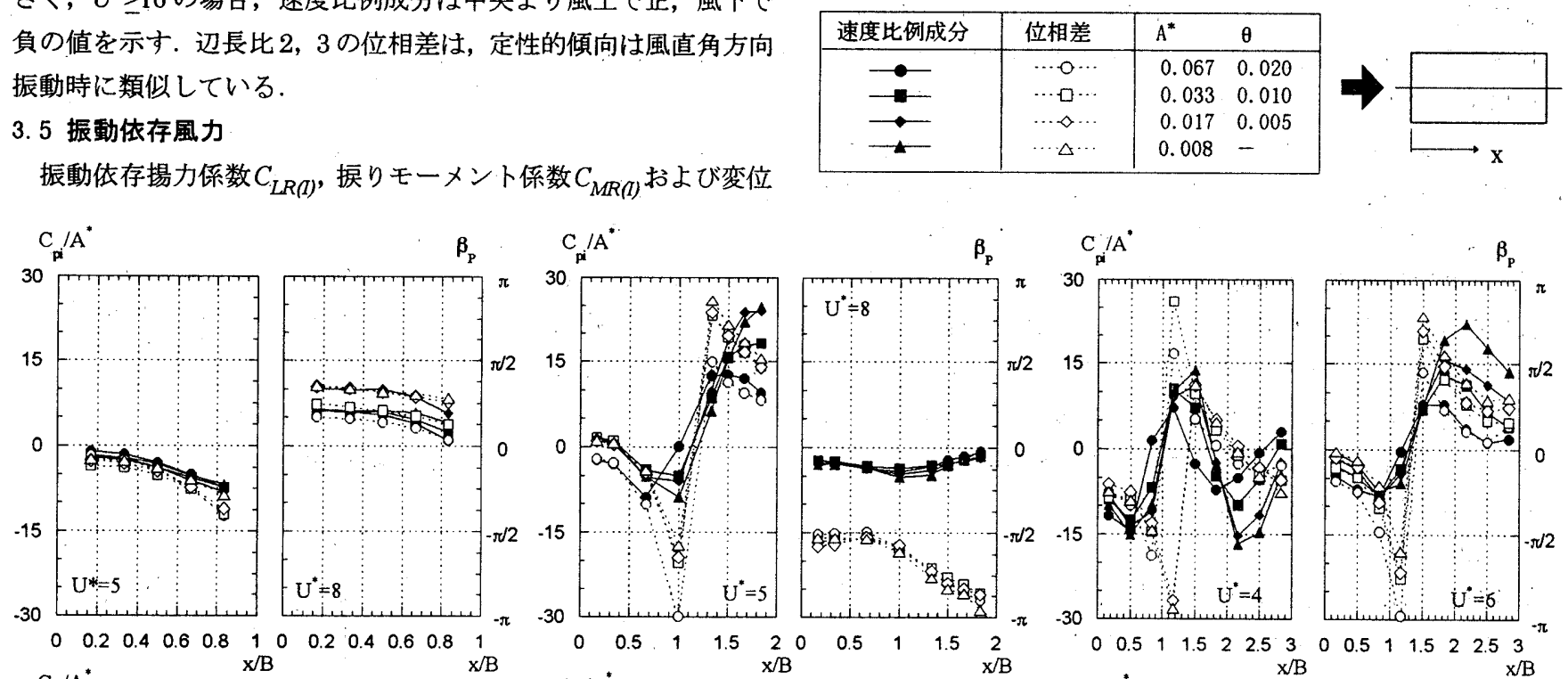

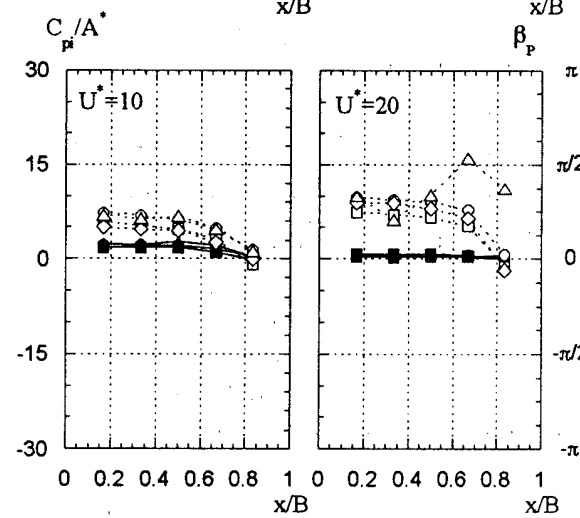

(1) 辺長比 1

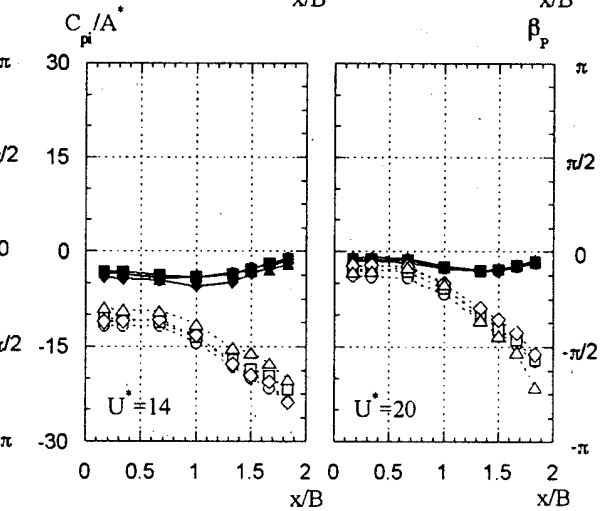

(2) 辺長比 2

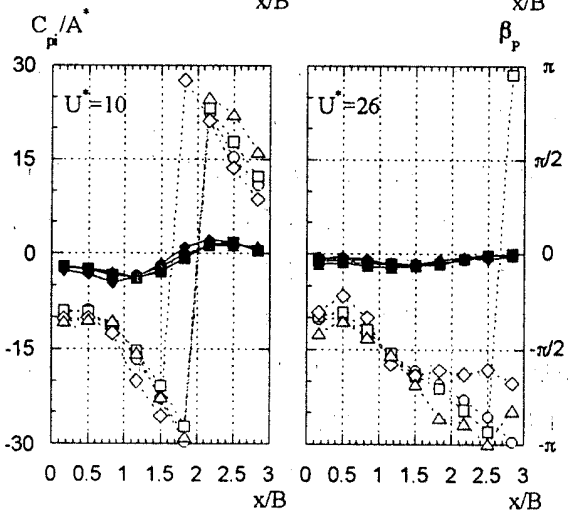

(3) 辺長比 3

（a）風直角方向振勳時
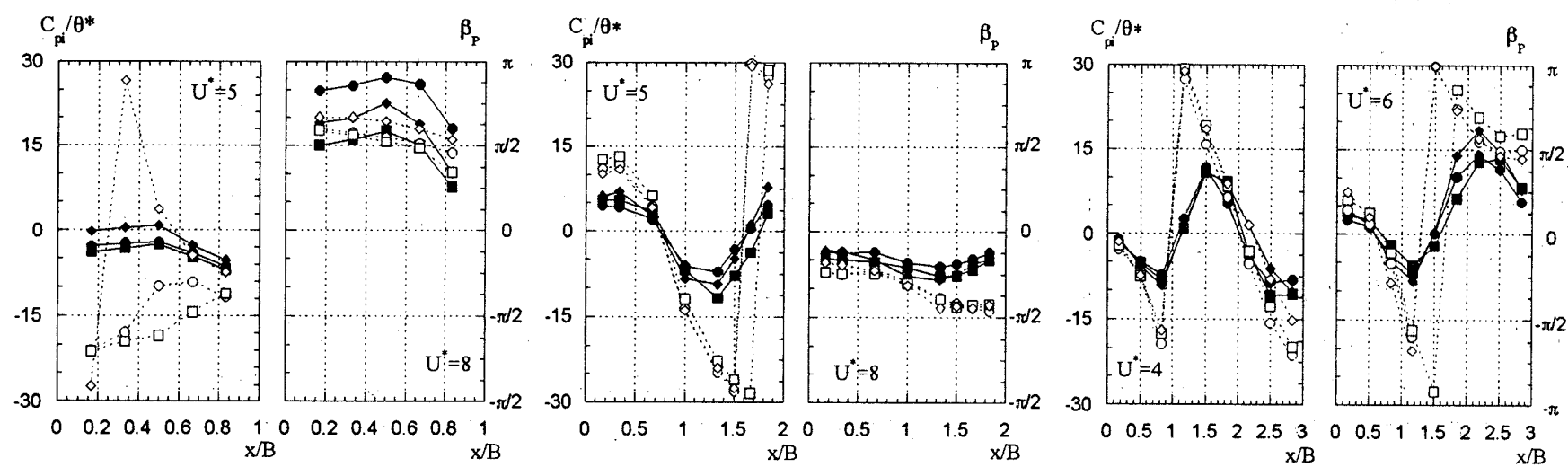

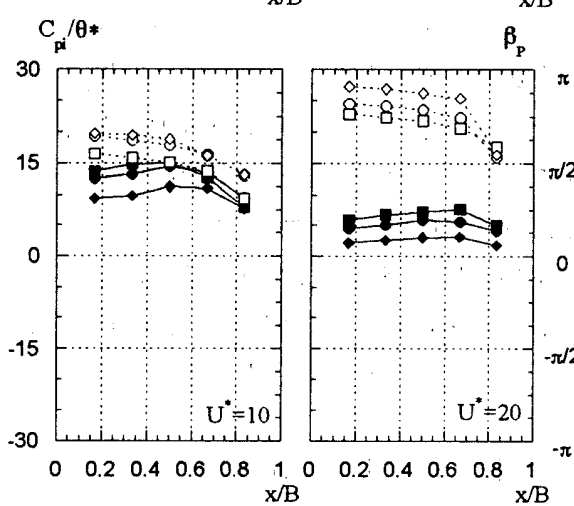

(1) 辺長比 1

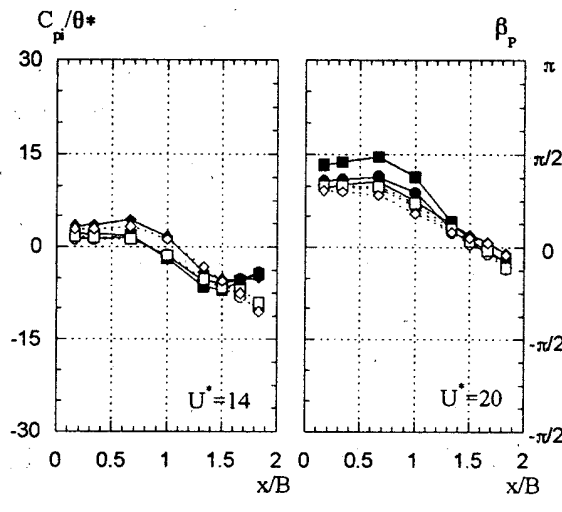

(2) 辺長比 2

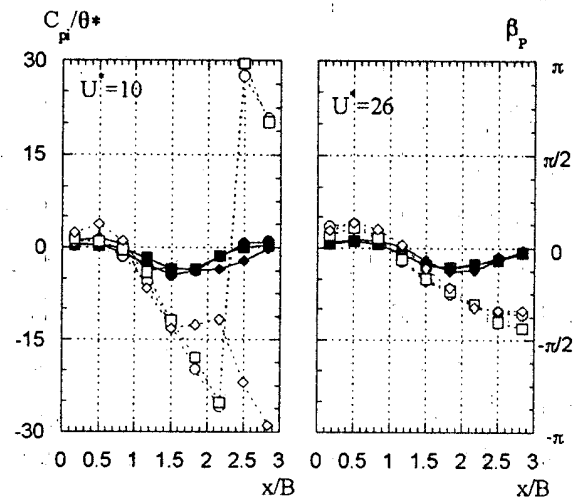

(b) 挨れ振動時

(3) 辺長比 3 
との位相差 $\beta_{L(M)}$ は, 振動依存風圧係数より下式により求めた.

$C_{L R(I)}=\frac{1}{D} \sum_{\text {上下面 }} C_{P R(I)} \Delta \ell$

$C_{M R(I)}=\frac{1}{D^{2}} \sum_{\text {全面 }} C_{P R(I)} \ell_{s} \Delta \ell$

$\beta_{L(M)}=\tan ^{-1}\left(\frac{C_{L(M) I}}{C_{L(M) R}}\right)$

ここで, $\Delta \ell$ : 負担幅, $\ell_{s}$ : 断面中心からの距推であり, 添え字 $R$, $I$ はそれぞれ変位比例成分および速度比例成分を表す．なお，力 の向きは変位および回転角と同じ向きとした．振動依存風力も風 圧同様無次元加振振幅で基淮化した。

図-9および図-10に振動依存揚力係数および振動依存㧖りモー メント係数を示す.ここでは特に, 構造物の不安定振動に関係す る振動依存風力係数の速度比例成分および位相差について述べる. 風直角方向振動時 辺長比 1 の場合, 振動依存揚力係数の速度比 例成分は, $U^{*} \doteqdot U^{*}{ }_{S P}$ において負から正に急激に変化し正の極值を 示した後, 無次元風速の増加に伴い指数的に減少する. 辺長比 2 , 3 の場合, 速度比例成分の值は $0.8 U^{*}{ }_{S P} \leq U^{*} \leq 1.2 U^{*}{ }_{S P}$ の範囲で正 の值を示し, $U^{*} \doteqdot U^{*}{ }_{S P}$ で極大となる. 辺長比 2 では, $U^{*} \geq 27$ の高 風速で再び正值を示寸傾向が見られるが, 辺長比 3 ではこの傾向 は見られない. 辺長比 $1 \sim 3$ のいずれにおいても $U^{*} \doteqdot U_{S P}^{*}$ を除き 振動依存風力は加振振幅にほぼ比例する. $U^{*} \doteqdot U_{S P}^{*}$ では加振振幅 が大きなほど振動依存風力が小さくなる傾向を示す.

風直角方向振動時の位相差は, 辺長比 $1 \sim 3$ のいずれの場合も $U^{*} \doteqdot U_{S P}^{*}$ で急激に変化し, $U^{*} \geq 10$ の高風速では緩やかな変化を示 す. $U^{*} \doteqdot U_{S P}^{*}$ の位相変化は, 辺長比 1 の場合に最も著しい.

据れ振動時 辺長比 1 の場合, 振動依存据りモーメント係数の速 度比例成分は $U^{*} \doteqdot U^{*}{ }_{S P}$ および $U^{*} \doteqdot 0.5 U^{*}{ }_{S P}$ で正の值を示寸. 辺長 比 2 の場合, 速度比例成分の值は $U^{*} \doteqdot U^{*}{ }_{S P}$ から正となり, $U^{*} \doteqdot$ $1.2 U^{*}{ }_{S P}$ で正の極值を示寸. 無次元風速の增加に伴い速度比例成分 の值は小さくなるが， $U^{*} \geq 10$ で再び増加し， $U^{*} \doteqdot 20$ においてふた たび極大值となる. 辺長比 3 の場合, 速度比例成分は $U^{*} \doteqdot 0.5 U^{*}{ }_{S P}$ および $U^{*} \geq 10$ において正の值を示す. $U^{*} \doteqdot U^{*}{ }_{S P}$ における加振振幅 による振動依存風力の変化は㧖れ振動の場合風直角方向振動時ほ ど明瞭ではなく, 振動依存風力は概ね加振振幅に比例する.

据れ振動時の位相差の風速による変化の定性的傾向は風直角方 向振動時と同様である.

以上の結果を一様流中での実験結果 ${ }^{10), 11)}$ と比較した場合, 辺長 比 2 の風直角方向振動時の振動依存揚力において明瞭な差が見ら れる. 一様流中の場合, 振動依存揚力は, $U^{*} \doteqdot 15$ 前後において位 相差の急激な変化に伴って速度比例成分が負から正に変化する. 一方, 本研究の一様乱流中の結果ではこのような傾向は示さず, 振 動依存風力の急激な変化は見られない.これは, 辺長比 2 の場合, 一様流中では後流域にカルマン渦が形成されるのに対し, 乱流中 では流れの再付着によってカルマン渦が形成されないためである.

\section{4. 振動依存風力を考慮した応答予測}

本研究で測定された振動依存風力係数を用いてスペクトルモー ダル法により応答解析を行い, 大熊他による二次元模型の自由振 動実験結果 $\left.{ }^{12}\right)$,13),14) と比較する. なお, 自由振動実験は, 本研究
と同じ形状の模型および気流を用いて行われたものである.

\section{1 応答解析方法}

並進振動を例に取ると，振動依存風力を変位・速度比例成分で 表した場合の振動方程式は周波数領域で表すと次式のようになる.

$\left[-(2 \pi f)^{2} M_{S}+i(2 \pi f) C_{S}+K_{S}\right] \xi(f)$

$$
=F_{W}(f)+F_{a R}(f)+i F_{a I}(f)
$$

ここで, $M_{S}$ :一般化質量， $C_{S}:$ 一般化減衰， $K_{S}:$ 一般化剛性， $F_{W}(f)$ : 一般化外力, $F_{a R(I)}(f)$ : 振動依存一般化風力の変位 (速度) 比例成分, $\xi(f)$ :一般化変位, $i=\sqrt{-1}$ である.

右辺の振動依存風力を左辺に移項して整理すると, 振動方程式 は以下のようになる。

$K_{S}\left[1-\left(\frac{f}{f_{0}}\right)^{2}+\left(\frac{K_{a}}{K_{S}}\right)+i 2(h s+h a)\left(\frac{f}{f_{0}}\right)\right] \xi(f)=F_{W}(f)$

ここで, $f_{0}$ : 固有振動数, $K_{a}$ :一般化空力剛性, $h s$ :一般化構造减 衰定数, $h a:$ 一般化空力減衰定数である.

振動モードを一様とするとKa/Ksおよびhaは下式のようになる.

$\frac{K_{a}}{K_{S}}=-\frac{1}{8 \pi^{2}} \frac{\rho_{a}}{\rho_{S}}\left(\frac{U}{f_{a} B}\right)^{2} \frac{1}{A^{*}} C_{L R}\left(\frac{U}{f_{a} B}\right)$

$h a=-\frac{1}{16 \pi^{2}} \frac{\rho_{a}}{\rho_{S}}\left(\frac{U}{f_{a} B}\right)^{2} \frac{1}{A^{*}} C_{L I}\left(\frac{U}{f_{a} B}\right)$

$f_{a}=f_{0} \sqrt{1+\frac{K_{a}}{K_{S}}}$

ここで, $f a$ : 見か十忛上の構造物の固有振動数, $\rho_{a}$ : 空気密度, $\rho_{S}$ : 構造物の密度である.

したがって, 応答変位の標淮偏差は振動依存風力を考慮した場 合, 下式のようになる。

$$
\sigma_{\xi}=\frac{\sigma_{F W}}{M_{S}\left(2 \pi f_{0}\right)^{2}} \sqrt{\int \frac{S_{F W}(f)}{\sigma_{F W}^{2}}|\chi(f)| d f}
$$

$|\chi(f)|=\frac{1}{\left\{1-\left(f / f_{0}\right)^{2}+K_{a} / K_{S}\right\}^{2}+4(h s+h a)^{2}\left(f / f_{0}\right)^{2}}$

ここで, $\sigma_{F W}$ :一般化外力の標準偏差, $S_{F W}(f)$ :一般化外力のパワー スペクトル密度である。

本研究の応答解析では, 風外力および振動依存風力は中央部分 での測定值を用いた．スパン方向の風外力および振動依存風力の 分布は一様, 風力相関注完全相関とし, 変位に対する振動依存風 力の位相差はスパン方向に一定とした. また, 振動依存風力は振 幅に比例するとして, 空力減衰および空力剛性は実験を行った最 大加振振幅の振動依存風力を 3 次元スプライン関数で補間したも のを用いて (5) 式および (6) 式より求めた.

\section{2 応答予測結果}

図-11に応答変位の標準偏差の予測值と自由振動実験值との比較 を示す.なお, 図中に示した質量減衰パラメーターはそれぞれ $S_{C L}=2 \pi h s M / \rho_{a} B D L, S_{C M}=2 \pi h s I / \rho_{a} B^{2} D^{2} L(M:$ 模型の質量, $I:$ 模 型の回転慣性モーメント)である.

振動依存風力を考慮した応答予測值は, 振動依存風力を考慮し ない場合に比べ実験值により近い結果が得られている.しかし, 質 量減衰パラメーターが小さな場合, $U^{*} \doteqdot U^{*}{ }_{S P}$ の予測值が実験值に 比べ大きく, また, 辺長比 2 の風直角方向の渦励振および㧖れ〉 

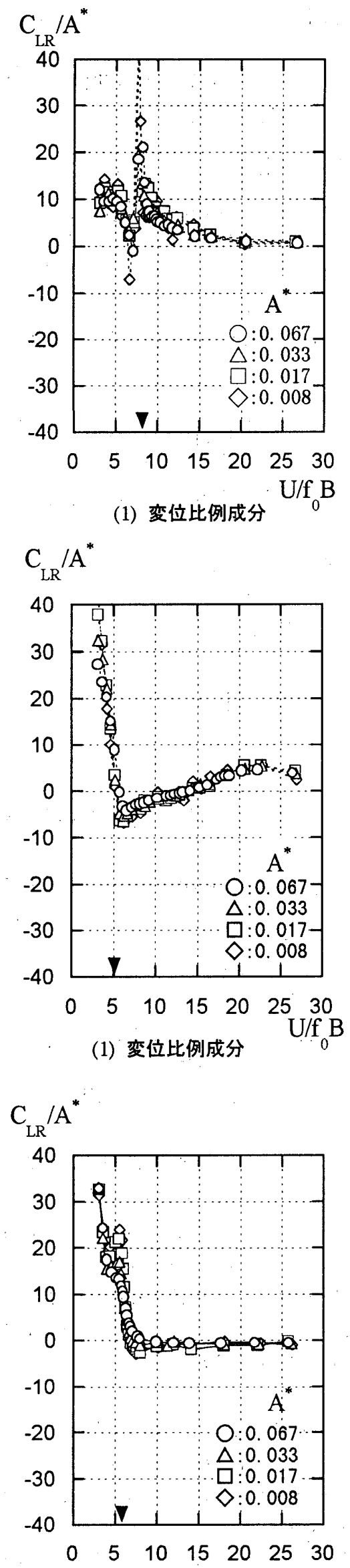

(1) 変位比例成分

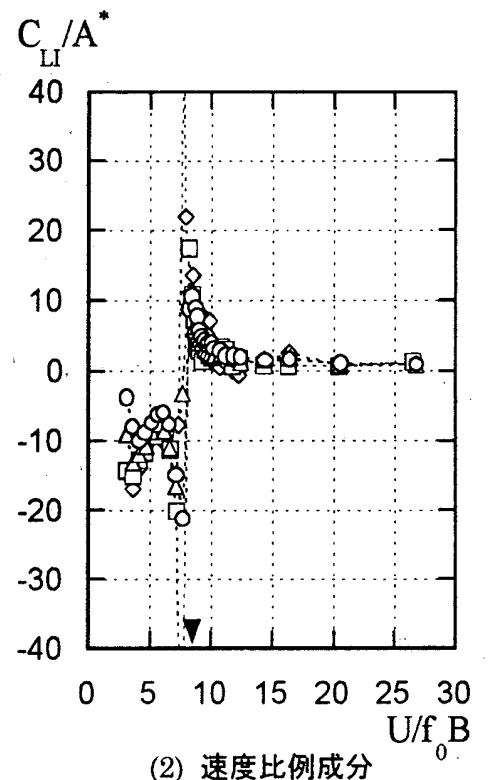

(a) 辺長比 1

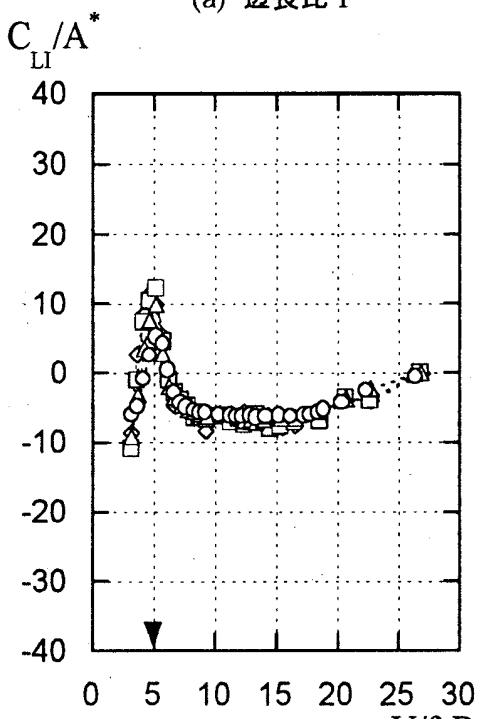

(2) 速度比例成分 U/f $B$

(b) 辺長比 2

$\mathrm{C}_{\mathrm{LI}} / \mathrm{A}$

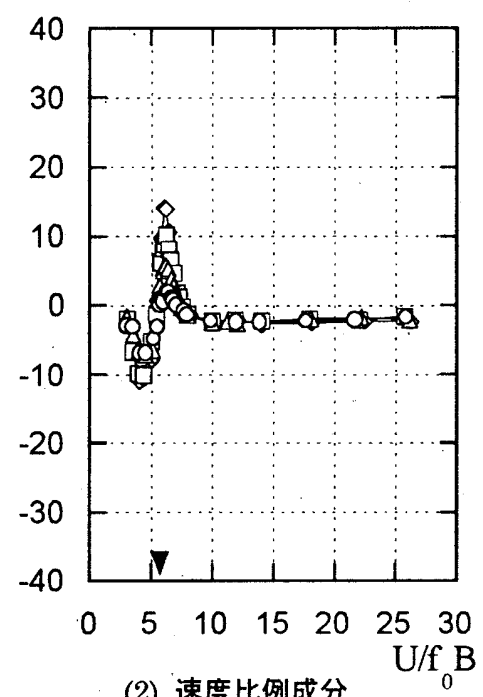

(2) 速度比例成分

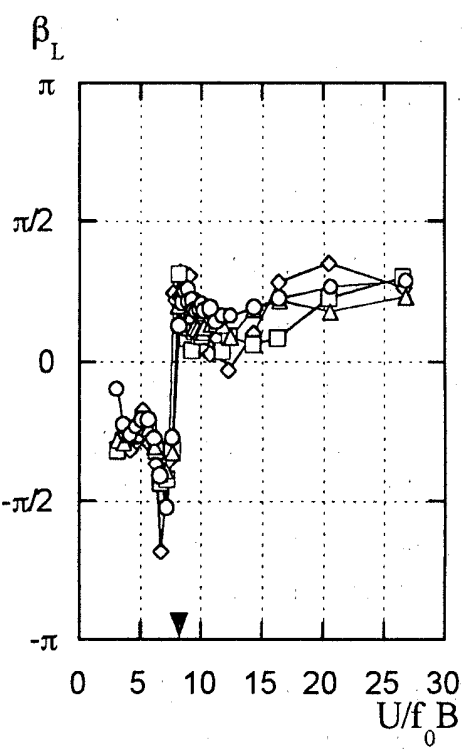

(3) 位相差

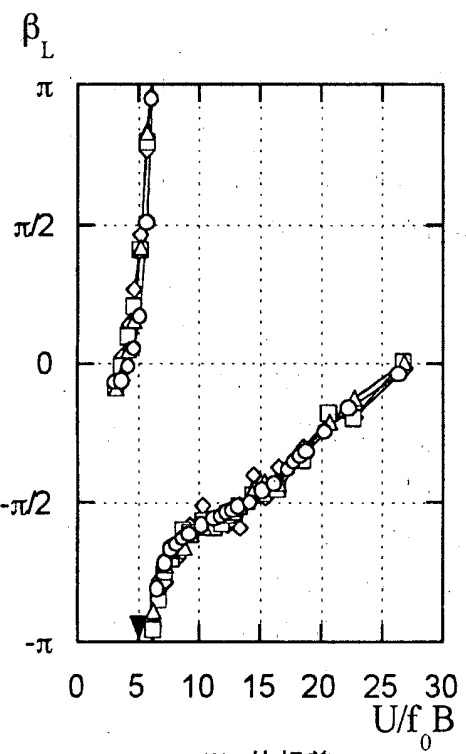

(3) 位相差

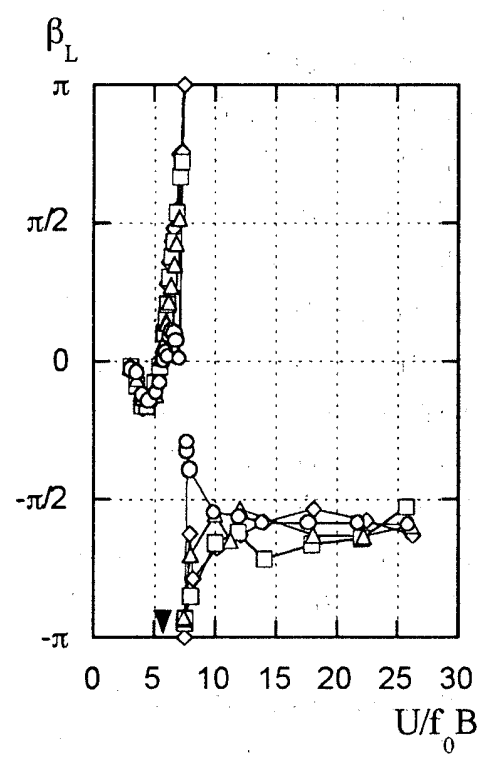

(3) 位相差

図 -9 風直角方向振動時の振動依存揚力係数および位相差（、は $U_{S P}^{*}$ を示す） 


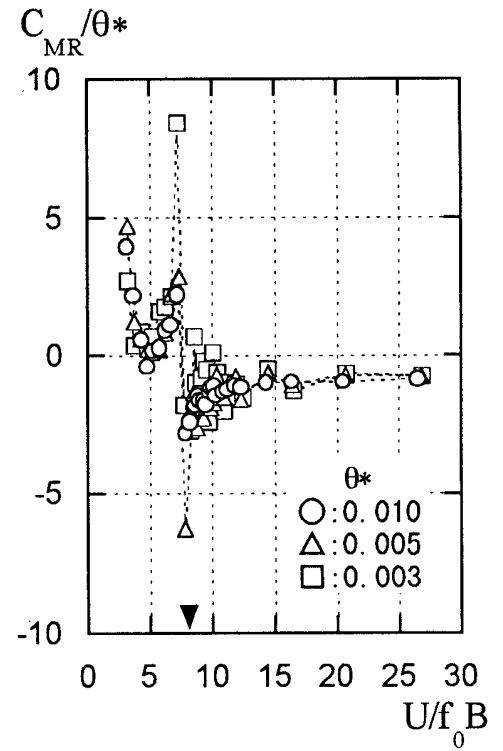

(1) 変位比例成分

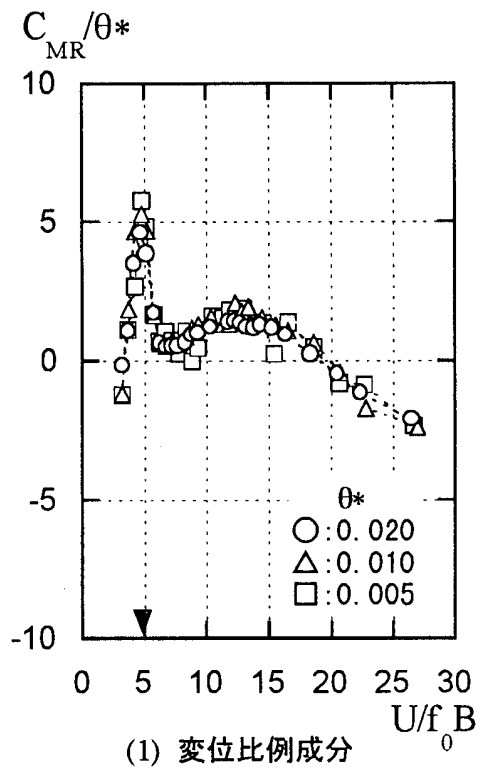

$\mathrm{C}_{\mathrm{MR}} / \theta *$

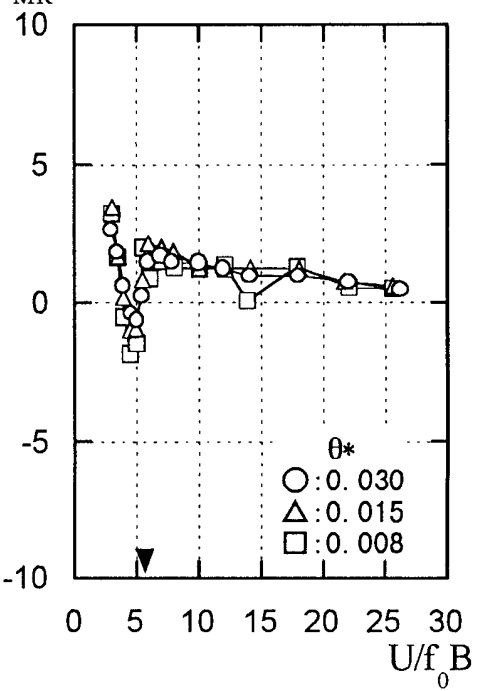

(1) 変位比例成分

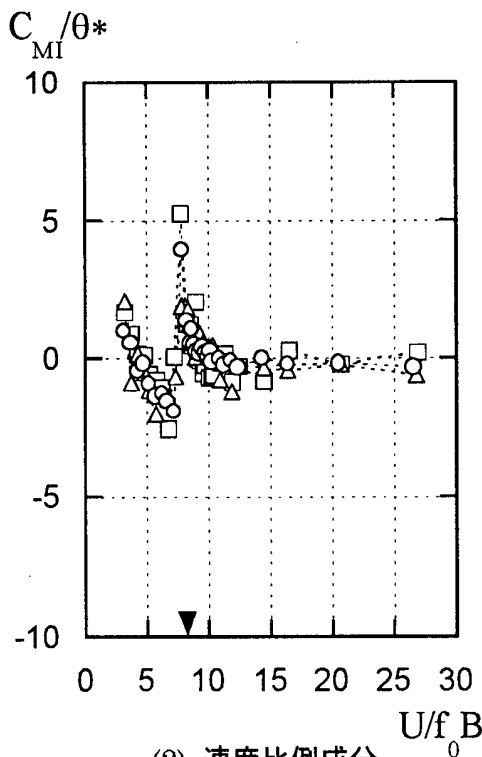

(2) 速度比例成分

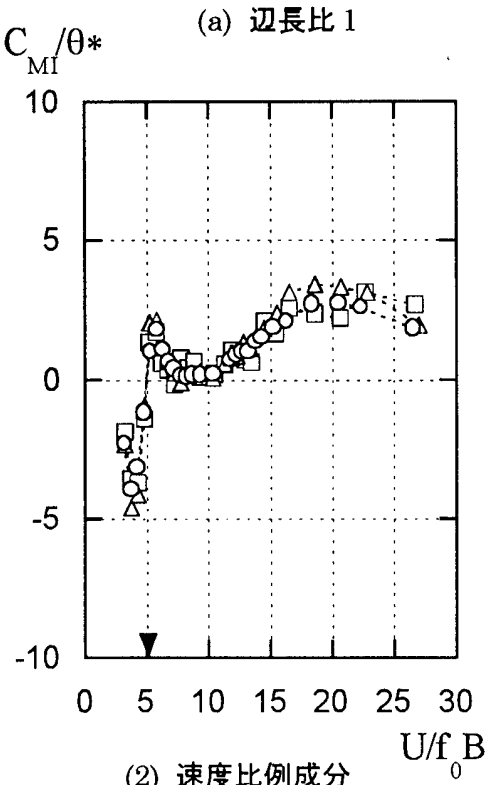

(b) 辺長比 2

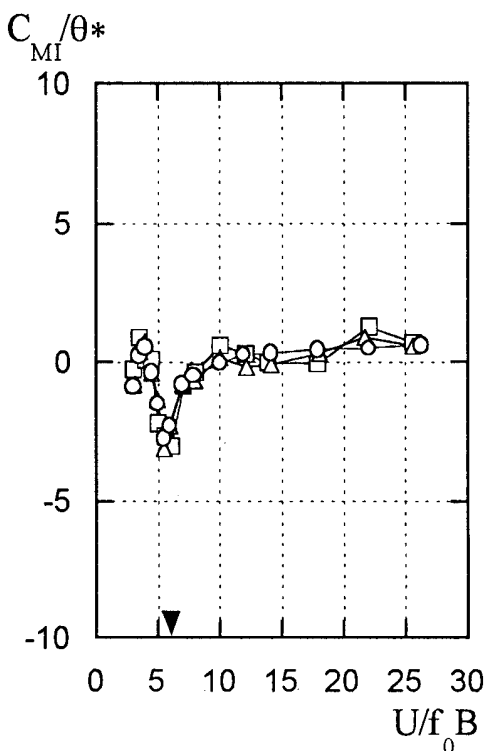

(2) 速度比例成分

(c) 辺長比 3

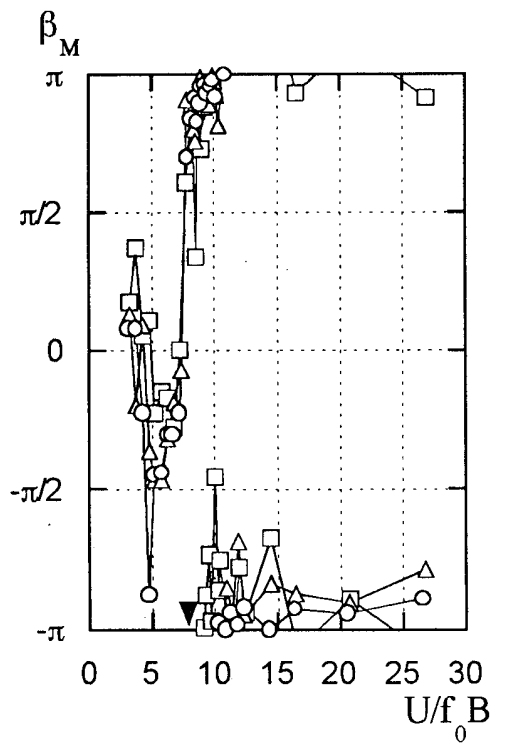

(3) 位相差

$\beta_{M}$

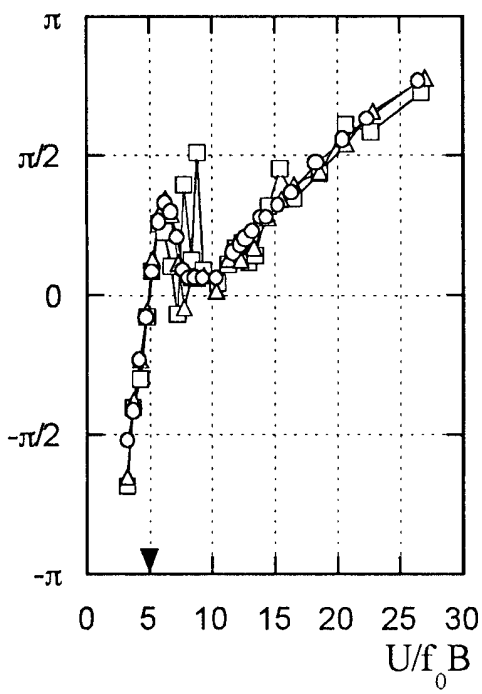

(3) 位相差

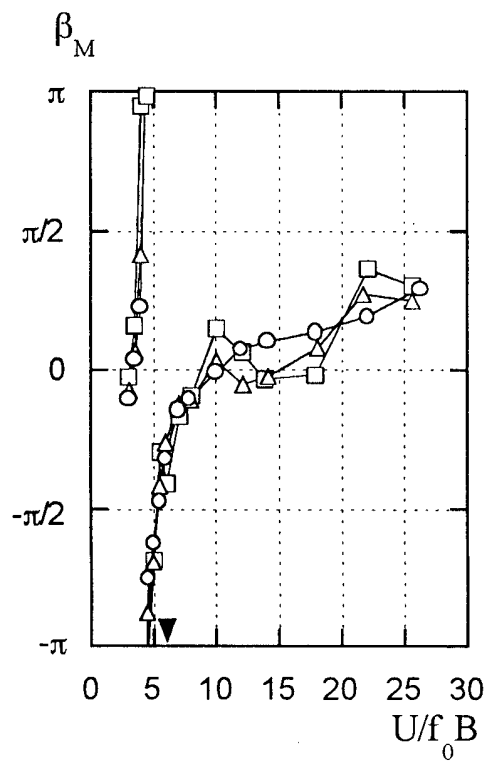

(3) 位相差

図-10 㨭れ振動時の振動依存㧖りモーメント係数および位相差( $\mathbf{\text { は }} U^{*}{ }_{S P}$ を示す) 
ラッターの生じる無次元風速が異なる.この内, $U^{*} \doteqdot U^{*}{ }_{S P}$ の時, 実 験值に比較し予測值が大きな值となるのは, 自由振動実験での振幅 が本実験の加振振幅に比べ大きな值が生じており,本実駼結果およ び文献 10)，11)に示されているよう.に振動依存風力が振幅に対して 非線形に変化するためと思われる. 辺長比 2 の自励振動の発振風速 が振動実験結果と異なること, 特に, 据れフラッターの発振風速が 異なることは, 無次元風速 8 および 14 の振動依存風圧の性状より 判断して㧖れフラッターが流れの再付着性状に大きく依存すると思 われることより,強制振動実験と自由振動実験の振動性状および端 板付近での気流性状の違いなどに起因するものと考えられる.

\section{5. 結論}

一様乱流中における矩形断面構造物に作用寸る振動依存風力特性 について二次元模型を用いた風洞実験により明らかにした．また， 測定した振動依存風力を用いて応答予測を行い,自由振動実験結果 との比較を行った。結果は以下のとおりである.

1) 風直角方向振動の場合, 辺長比 $1 \sim 3$ の断面では $U^{*} \doteqdot U_{S P}^{*}$ にお いて振動依存風力の速度成分が:正值の極大值を示す.

2）据れ振動の場合, 辺長比 1 では $U^{*} \doteqdot U^{*}{ }_{S P}$ において振動依存風力 の速度成分が正值の極大值を示す．辺長比 2 では， $U^{*} \doteqdot U^{*}{ }_{S P}$ およ びU*广20において正值の極大值を示す，辺長比 3 では $U^{*} \doteqdot U^{*}{ }_{S P}$ で 正值とならず $U^{*} \geq 10$ において正の值を示す.

3) 測定した振動依存風力を考慮した応答予測值は, 振動依存風力 を考虑しない場合に比べ自由振動実験結果により近い結果が得られ た.しかし，質量减衰パラメーターが小さな場合，不安定振動の生 じる風速範囲では応答予測值は実験值より大きな值となった.

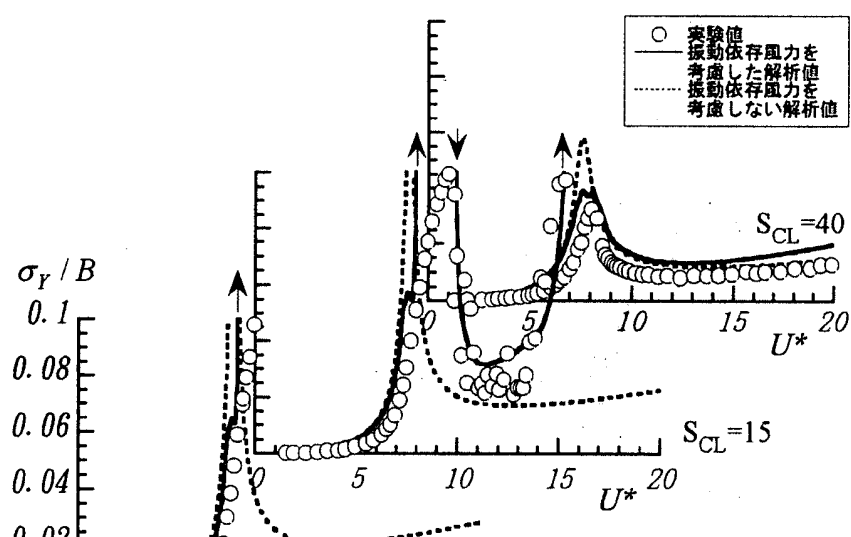

(a) 辺長比 1 , 風直角方向振動

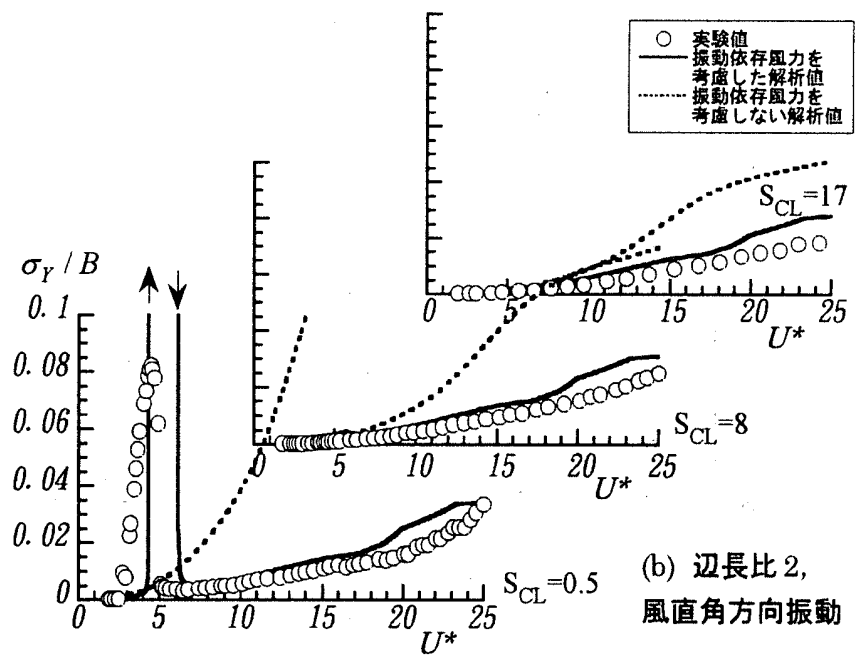

\section{参考文献}

1) 例えは Parkinson, G.V., Wind-induced instability of structures, Phil. Trans. Roy. Soc. Lond. A.269, 1971

2) 例えぼ 白石成人, 松本勝, 渦励振の発生機構と志答評価, 日本風工学会誌第 20 号, 1984 年 6 月

3) 山田均, 宮田利雄, 伊藤学, たわみ振動する角柱の周辺風圧分布に関する一考察, 第 6 回風工学シンポジウム論文集, 1980 年 11 月

4) 松本勝, 白石成人, 白土博通, 真下義章, 湯川雅之, 平井滋登, 各種空力振動胃象に及 ぼす乱れの影響, 第 10 回風工学シンポジウム論文集 1988 年 12 月

5)谷池義人, 京都大学博士学位論文, 1983 年

6)Steckley A., Ph.D thesis The University of Western Ontario, 1989

7) 小林紘士，川谷充朗，金熙㥁，上島秀作，乱流中における角柱の渦励振時の動的圧力 特性, 日本風工学会誌，第 47 号，1991 年 4 月

8) 河井宏允, 高首建筑物の渦励振, ギャロッピング, フラッター, 第 12 回風工学シンポ ジウム論文集, -1992 年 12 月

9) 山田均, 宮田利雄, 山下幸俊, 長方形断面柱のたわみ瀜励振時の剥離流に対する初期 迎角の支配効果, 第 7 回風工学シンポジウム論文集, 1982 年 12 月

10) Nakamura, Y. and Mizota, T. , Unsteady lifts and wakes of oscillating rectangular prisms, J. Eng. Mech. Div., Proc. of ASCE 101, EM6, 1975,12

11) 就津久一郎, 大屋昭男, 大筑志夫, 藤井邦雄, 箱型模型の空力弹性特性に関する風 洞実験, 第 4 回風工学シンポジウム論文集, 1976年 12 月

12)大熊武司, 丸川比佐夫, 山本学, 鶴見俊雄, 矩形断面構造物の風直角方向空力不安定 振動に関する実験的研究, 日本建築学会大会学術講演梗概集 (関東) 1993 年 9 月

13)大熊武司，丸川比佐夫，山本学, 矩形断面構造物の㨝れ空力不安定振動に関する実験 的研究, 日本建筑学会大会学術講演梗概集 ( 北海道)1995 年 8 月

14)山本学, 矩形断面構造物の空力不安定振動の時刻歷解析に関する研究, 神奈川大学大 学院 1994 年度修士論文

15) 丸川比佐夫, 大熊武司, 鶴見俊雄, 山本学, 百村幸男, 矩形断面構造物に作用する振 動依存風力特性に関する基礎的研究，第 12 回風工学シンボジウム論文集，1992年 12 月
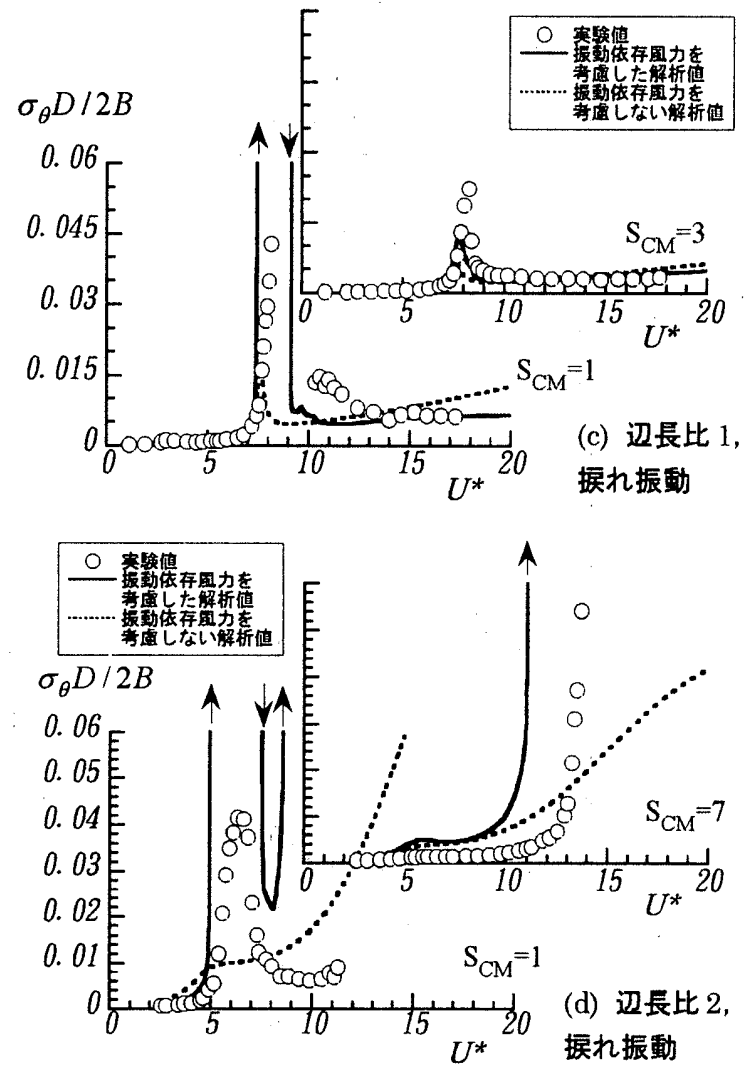

図-11 応答解析結果

(1997年12月10日原稿受理, 1998年 5 月 8 日採用決定) 